\title{
DESCRIPTION OF A NEW WATER MITE SPECIES OF THE GENUS RHYNCHATURUS BESCH, 1964 (ACARI, HYDRACHNIDIA: HYGROBATIDAE) FROM CHILE
}

\author{
Petr V. Tuzovsky ${ }^{1 *}$ and Vitaly A. Stolbov ${ }^{2}$
}

\author{
${ }^{1}$ Institute for Biology of Inland Waters, Russian Academy of Sciences, Borok, Yaroslavl Prov., Russia \\ ${ }^{2}$ Tyumen State University, Tyumen, Russia \\ *corresponding author; e-mail: tuz@ibiw.yaroslavl.ru
}

ABSTRACT: A description of a new water mite species Rhynchaturus magellanicus from the running waters of Chile is presented.

KEY WORDS: Water mite, Rhynchaturus magellanicus, male, female, morphology.

DOI: 10.21684/0132-8077-2017-25-1-51-54

\section{INTRODUCTION}

The aim of this paper is to describe the male and female of a new water mite species of the genus Rhynchaturus Besch, 1964 from Chile.

The material was collected by V. Stolbov in 2014 in the running waters in Chile. The material was sampled with a common hand net with 250 $\mu \mathrm{m}$ mesh size. Mites were fixed $75 \%$ ethanol. Idiosomal setae and slit organs are named according to Tuzovsky (1987): $F c h$-frontales chelicerarum, $\mathrm{Fp}$-frontales pedipalporum, $\mathrm{Vi}$-verticales internae, $\mathrm{Ve}$ - verticales externae, $\mathrm{O} i-$ occipitales internae, $\mathrm{Oe}$ - occipitales externae, $\mathrm{Hi}$-humerales internae, $\mathrm{He}$-humerales externae, $\mathrm{Hv}$-humerales ventralia, $S c i$-scapulares internae, $S c e$-scapulares externae, $L i$-lumbales internae, $L e$-lumbales externae, $\mathrm{Si}$ - sacrales internae, $\mathrm{Se}$ - sacrales externae, $\mathrm{Ci}$-caudales internae, $\mathrm{Pi}$ - - praeanales internae, $P e$ - praeanales externae; $i 1-i 5$-slit organs.

Furthermore, the following abbreviations are used: P-1-5, pedipalp segments (trochanter, femur, genu, tibia and tarsus) i.e. P-3=genu; ac-1-ac-3, genital acetabula 1-3; I-Leg-1-6, first leg, segments 1-6 (trochanter, basifemur, telofemur, genu, tibia and tarsus) i.e. III-Leg-1=trochanter of third leg; L-length; W-width; H-height, D - diameter; $\mathrm{n}=$ number of specimens measured. All measurements are given in micrometers $(\mu \mathrm{m})$ and the length of the appendage segments is dorsal length.

\section{DESCRIPTION}

\section{Rhynchaturus magellanicus Tuzovskij et Stolbov, sp. $\mathbf{n}$.}

(Figs. 1-9)

Type material. Holotype: male, slide \# 9876, South America, Chile, Region de Magallanes y de la Antartica Chilena, Provincia de Magallanes, stream to the south of Punta Arenas city (53'34'29" S 7056'23” W), depth $0.4 \mathrm{~m}$, substrates: stones and mosses, 08 November 2014, leg. V. Stolbov. Paratypes (one male and one female) collected have same data and locality as holotype. All specimens mounted in Hoyer medium. The holotype is deposited in the collection of the Institute for Biology of Inland Waters (Borok, Russia).

Diagnosis. Both sexes: Dorsal and ventral shields present; idiosoma without posterolateral glandularia tubercles, camerostom comparatively short not reaching the tips of coxal plates I, genital acetabula small and separated from each other by more than the diameter of the acetabula. Male: gonopore located in the anterior half of the acetabular plate. Female: acetabular plates with widely rounded anterior end.

Male. The idiosoma is flat, nearly circular (ratio L/W 1.09-1.12) and truncate anteriorly. Dorsal and ventral shields present. Lateral eyes not in capsules, eye pigment present. Fig. 1 shows the characteristic cuticular thickenings of the dorsum. Dorsal shield consisting of six pairs of closely fitting central platelets, anterior pairs of platelets bearing trichobothria $O i$, two pairs of central platelets lacking setae, three lateral pairs of platelets bearing setae $\mathrm{Oe}, \mathrm{Hi}$ and $\mathrm{Li}$, respectively. Peripheral part of dorsum divided into two unpaired sectors (anterior and posterior) and three pairs lateral sectors; anterior sector much larger than posterior one. Setae Fch, Fp, Vi, Ve, Hi, Sci, Le, Si and slit organs (il-i4) situated along lateral margin of dorsum.

The ventral shield without posterolateral glandularia tubercles (Fig. 2). The camerostom pointed and not reaching of the tips of coxal plates I. Anterior coxal groups with short posterior apodemes directed laterally. Setae and glandularia $H v$ located 


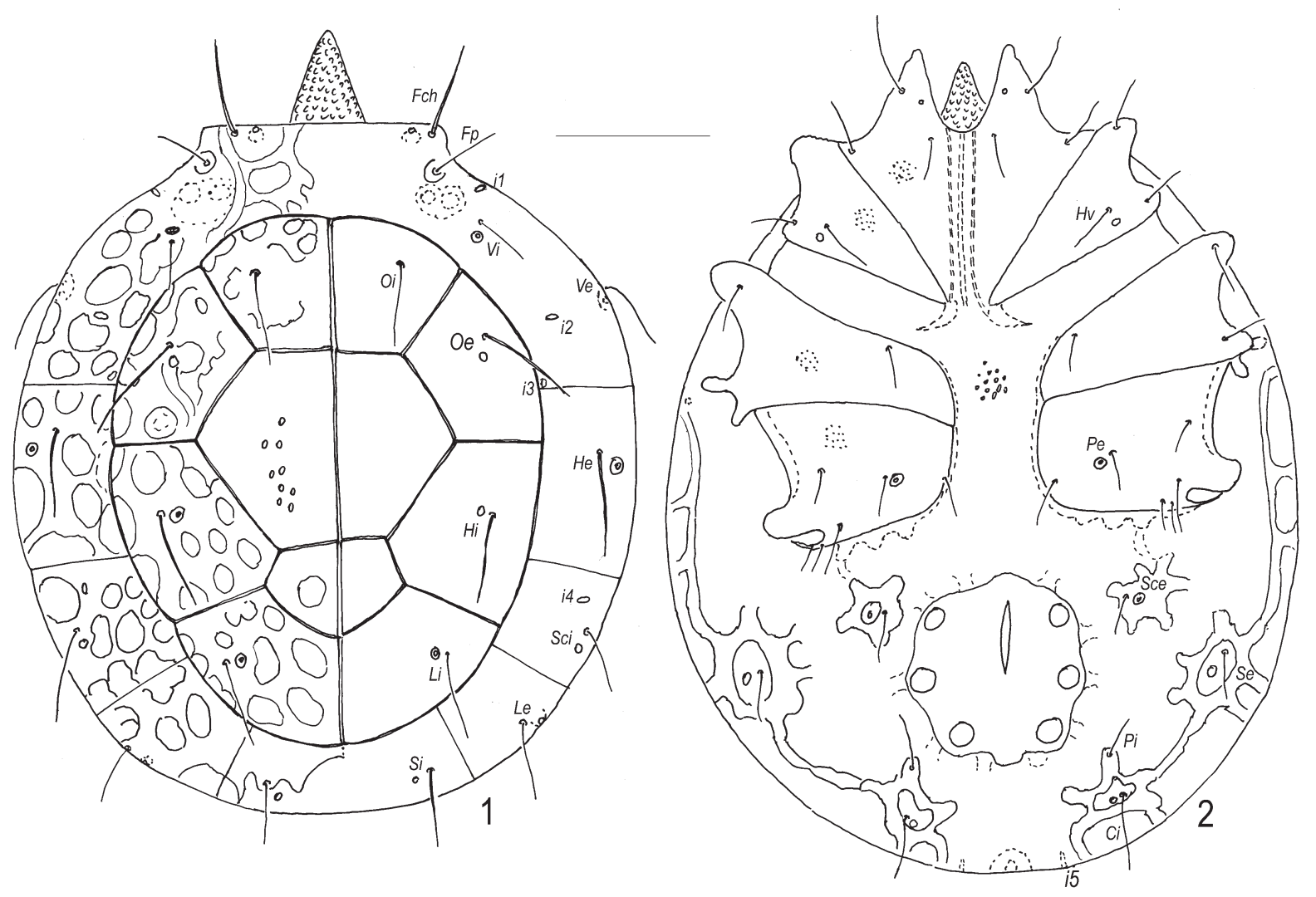

Figs. 1-2. Rhynchaturus magellanicus, sp. n.: 1—dorsal view; 2-ventral view. Scale bar: $100 \mu \mathrm{m}$.

on coxal plates II posterolaterally, setae and glandularia $P e$ on the coxal plate IV located far posterior to the suture line between coxal plates III+IV.

Genital plate subterminal, with three pairs of genital acetabula and 17-21 pairs of thin unequal setae (Fig. 3). Acetabula comparatively small and separated by more than the diameter of an acetabula; gonopore short narrow, located in the anterior half of genital plate. Setae and glandularia Sce and $S e$ surrounded by cuticular thickenings, setae $P i$ located on tips of narrow projections of cuticular thickenings. Excretory pore and $i 5$ located caudally.

Capitulum (Fig. 4) elongated (L/H ratio 4.04.1) and attached to a long tube of soft integument to produce greatly protrusible mouthparts. Chelicera with large basal segment and short chela.

Pedipalp (Fig. 5) compact: P-1 short, without setae; P-2 with two dorsal setae (proximal and distal); $\mathrm{P}-3$ shorter than $\mathrm{P}-2$, with single dorsodistal seta; $\mathrm{P}-4$ longer than $\mathrm{P}-2$, bearing only unequal thin distal setae; $\mathrm{P}-5$ relatively large and curved.

Legs without swimming setae. Shape and arrangement of setae on terminal segments of legs I and IV-Leg as shown in Figs. 6 and 7. I-Leg-1 with long distoventral seta, I-Leg-2 and I-Leg-3 with sword-like distoventral seta each, I-Leg-5-6 bearing only thin setae. All legs claws with three clawlets (Fig. 8), central and internal clawlets thicker than external clawlet; lamella with slightly convex ventral margin.

Measurements $(n=2)$. Idiosoma L 450-470; dorsal shields L 335-380, W 270-285; first dorsal platelets L 100-108,W 80-85; second dorsal platelets L 120-132, W 90-95; genital plate L 102-108, W 120-135; genital acetabula (ac-1-ac-3) L or D 18-21, 18-19, 15-19; capitulum L 192-198, H 48-50; cheliceral segments: base L 130-138, chela L 54-55; pedipalp segments (P-1-5) L: 15-16, 42-45, 27-30, 59-61, 30; leg segments L: I-Leg-1-6: 42-45, 54-60, 72-75, 120-128, 115-120, 90-92; II-Leg-1-6: 42-45, 54-60, 72-78, 114-117, 110-120, 95-97; III-Leg-1-6: 50-52, 48-51, 72-75, 115-125, 125-132, 95-97; IV-Leg-1-6: 80-90, 72-78, 90-102, 138-145, $155-$ 168, 114-120.

Female. Dorsum similar to male, but its peripheral part not divided on sectors. Genital field subterminal, acetabular plates separated with rounded anterior margin each and not fused with anterior genital sclerite, with three pairs of genital acetabula and 18-19 pairs of thin unequal setae (Fig. 9). Acetabula comparatively small and are separated by more than the diameter of an acetabula.

Measurements $(n=1)$. Idiosoma L 660, W 540; dorsal shields L 475, W 360; first dorsal platelets 

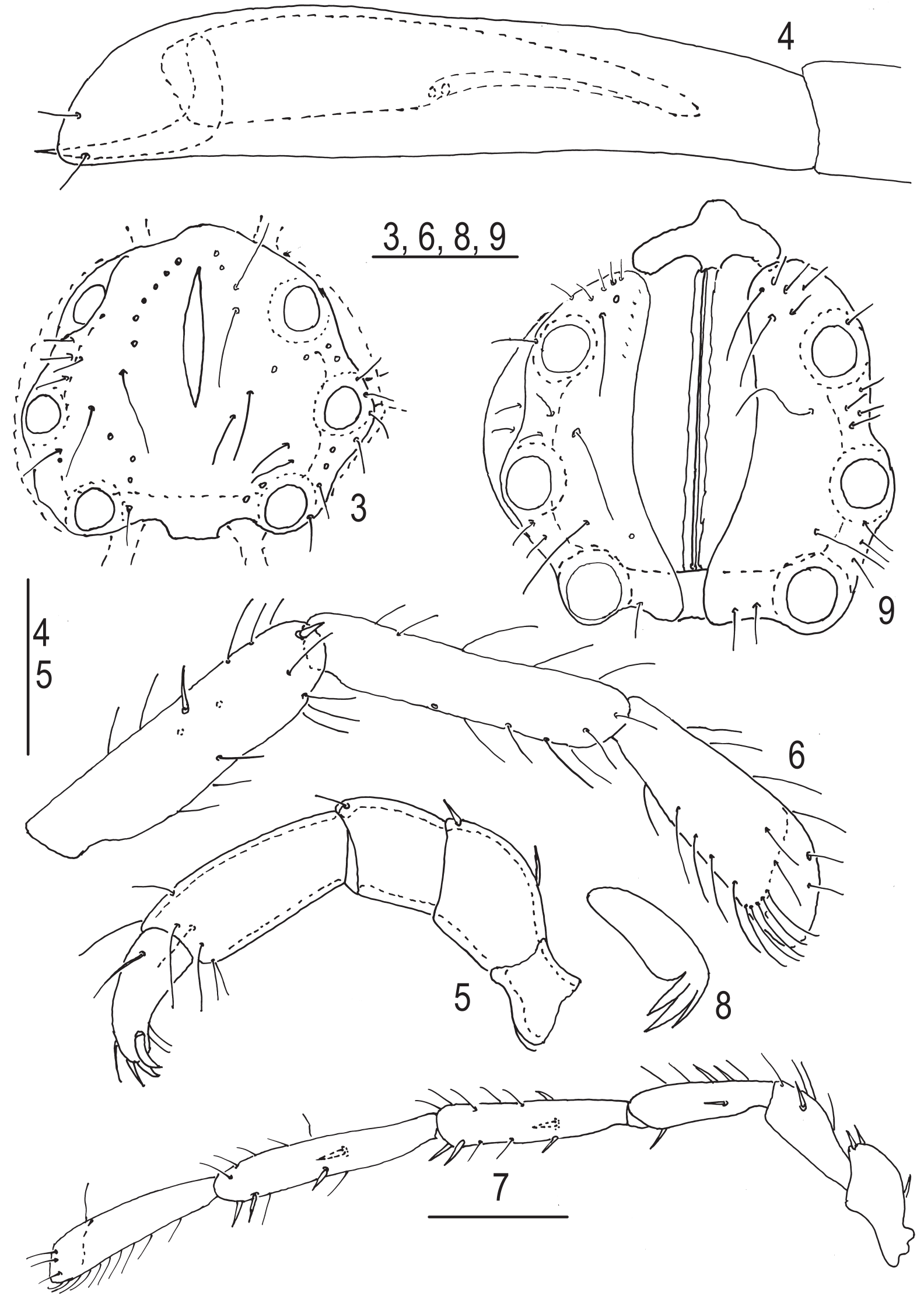

Figs. 3-9. Rhynchaturus magellanicus, sp. n.: 3, 9-genital field; 4-capitulum and chelicera, lateral view; 5-pedipalp, lateral view; 6-I-Leg-4-6, 7-IV-Leg-1-6, 8-claw; 3-8 - male, 9-female. Scale bars: 3-6, 8-9=50 $\mu \mathrm{m}, 7=100 \mu \mathrm{m}$. 

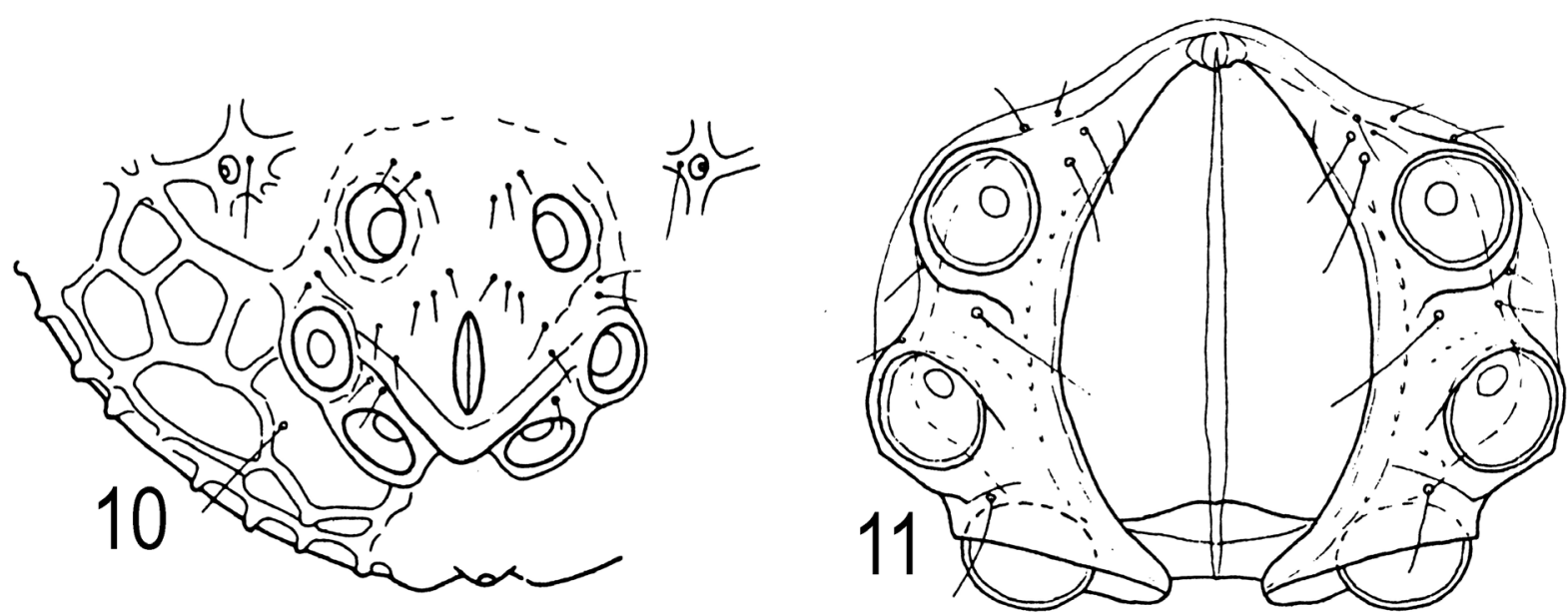

Figs. 10-11. Rhynchaturus hexaporus Besh, 1964: 10—genital field of male (after Cook 1974), 11—genital field of female (after Cook 1988).

L 138, W 125; second dorsal platelets L 170, W 125; genital plate L 126 , W 60; genital acetabula (ac-1-ac-3) L or D 24-25, 24-27, 22-27; capitulum L 240, H 69; cheliceral segments: base L 186, chela L 63; pedipalp segments (P-1-5) L: 30, 54, 36, 66, 30; leg segments L: I-Leg-1-6: 42, 60, 84, 138, 108, 78; II-Leg-1-6: 42, 60, 84, 138, 126, 108; IIILeg-1-6: 48, 60, 90, 145, 138, 108; IV-Leg-1-6: $102,90,112,168,185,155$.

Differential diagnosis. The present species is similar to Rhynchaturus hexaporus Besch, 1964 but differs in the following characters (character states of female $R$. hexaporus are given in parentheses, data from Cook 1974, 1980, 1988): Both sexes: the camerostom comparatively short not reaching of the tips of coxal plates I, Fig. 2 (extending beyond the tips of coxal plates I); the genital acetabula relatively small and separated from each other by more than the diameter of an acetabula, Figs. 2-3 (relatively large and separated from each other by less than the diameter of an acetabula, Fig. 10). Male: the gonopore located in the anterior half of the acetabular plate, Figs. 2-3 (in the posterior half of the acetabular plate, Fig. 10). Female: the acetabular plates with widely rounded anterior end, Fig. 9 (with pointed anterior end, Fig. 11).
Etymology. The species is named after the region (Magellan, from the English for Magallanes) where it was collected.

Habitat. Running waters.

Distribution. South America, Chile: Magellan Province.

\section{ACKNOWLEDGEMENTS}

The field work in Chile was supported by the grant \# 14-14-01134 from the Russian Science Foundation.

\section{REFERENCES}

Cook, D.R. 1974. Water mite genera and subgenera. Memoirs of the American Entomological Institute, 21, 1-860.

Cook, D.R. 1980. Studies on neotropical water mites. Memoirs of the American Entomological Institute, 31, 1-645.

Cook, D.R. 1988. Water mites from Chile. Memoirs of the American Entomological Institute, 42: 1-356.

Tuzovsky, P.V. 1987. Morfologiya i postembrional'noye razvitiye vodyanykh kleshchey [Morphology and Postembryonic Development in Water Mites]. Nauka, Moscow, 172 pp. (in Russian) 